\title{
Dynamic Hydrogen Production from Methanol/Water Photo-Splitting Using Core@Shell-Structured CuS@TiO Catalyst Wrapped by High Concentrated $\mathrm{TiO}_{2}$ Particles
}

\author{
Younghwan Im, ${ }^{1}$ Sora Kang, ${ }^{1}$ Kang Min Kim,, Taeil Ju, ${ }^{1}$ Gi Bo Han, \\ No-Kuk Park, ${ }^{3}$ Tae Jin Lee, ${ }^{3}$ and Misook Kang ${ }^{1}$ \\ ${ }^{1}$ Department of Chemistry, College of Science, Yeungnam University, Gyeongsan, Gyeongbuk 712-749, Republic of Korea \\ ${ }^{2}$ Plant Engineering Division, Institute for Advanced Engineering, 633-2 Goan-ri, Baegam-myeon, Cheoin-gu, Yongin-si, \\ Gyeonggi 449-863, Republic of Korea \\ ${ }^{3}$ School of Chemical Engineering, Yeungnam University, Gyeongsan, Gyeongbuk 712-749, Republic of Korea \\ Correspondence should be addressed to Misook Kang; mskang@ynu.ac.kr
}

Received 12 July 2013; Revised 1 August 2013; Accepted 1 August 2013

Academic Editor: Jiaguo Yu

Copyright (C) 2013 Younghwan Im et al. This is an open access article distributed under the Creative Commons Attribution License, which permits unrestricted use, distribution, and reproduction in any medium, provided the original work is properly cited.

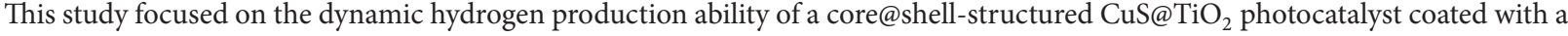
high concentration of $\mathrm{TiO}_{2}$ particles. The rectangular-shaped $\mathrm{CuS}$ particles, $100 \mathrm{~nm}$ in length and $60 \mathrm{~nm}$ in width, were surrounded

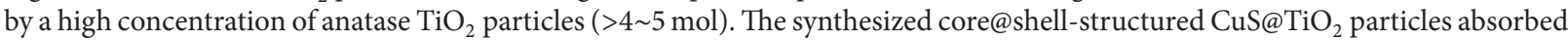
a long wavelength (a short band gap) above $700 \mathrm{~nm}$ compared to that pure $\mathrm{TiO}_{2}$, which at approximately $300 \mathrm{~nm}$, leading to easier electronic transitions, even at low energy. Hydrogen evolution from methanol/water photo-splitting over the core@shell-structured

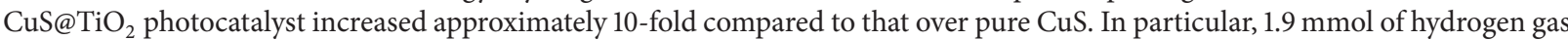

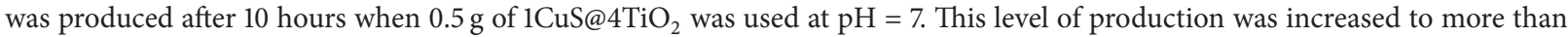
4 -fold at higher $\mathrm{pH}$. Cyclic voltammetry and UV-visible absorption spectroscopy confirmed that the CuS in $\mathrm{CuS} @ \mathrm{TiO}_{2}$ strongly withdraws the excited electrons from the valence band in $\mathrm{TiO}_{2}$ because of the higher reduction potential than $\mathrm{TiO}_{2}$, resulting in a slower recombination rate between the electrons and holes and higher photoactivity.
\end{abstract}

\section{Introduction}

In recent years, hydrogen has been highlighted as a nextgeneration energy source because of its environmentally friendly nature and high-energy efficiency. Therefore, hydrogen production has recently become the most active research topic globally. In particular, the technology for generating hydrogen by the splitting of water using a photocatalyst has attracted considerable attention. In the early days, the photocatalytic formation of hydrogen and oxygen focused extensively on metal-loaded or incorporated- $\mathrm{TiO}_{2}$ semiconductors due to the low band gap and high corrosion resistance of these materials [1-5]. On the other hand, hydrogen production from water photo-splitting using $\mathrm{TiO}_{2}$-based photocatalysts is ineffective because the amount of hydrogen produced is limited by the rapid recombination of holes and electrons over $\mathrm{TiO}_{2}$, resulting in the reformation of water [6]. In addition, more than $1.2 \mathrm{eV}$ is needed to decompose water [7], which means that the photodecomposition of water should be performed at UV wavelengths of approximately $260 \mathrm{~nm}$. Therefore, there is urgent need for the development of new and inexpensive photocatalysts that are both environmentally friendly and possess greater hydrogen-producing activity under visible light irradiation. Recently, studies of metal sulfide photocatalysts, such as ZnS- [8], CuS- [9, 10], FeS[11], $\mathrm{Bi}_{2} \mathrm{~S}_{3}-$ [12], $\mathrm{Sb}_{2} \mathrm{~S}_{3}$ - [13], or CdS-loaded $\mathrm{TiO}_{2}$ [14], have covered topics ranging from synthesis to applications in new photocatalytic reaction mechanisms. Narrow band gaps make it possible to absorb longer wavelengths compared to wide band gaps of conventional metal oxide semiconductor systems. A previous study reported high photocatalytic activity on the $\mathrm{ZnS}$-loaded $\mathrm{TiO}_{2}$ composite system for hydrogen 
production [15]. In that study, the evolution of $\mathrm{H}_{2}$ from methanol/water (1:1) photo-splitting over the $\mathrm{ZnS} / \mathrm{TiO}_{2}$ composite was enhanced dramatically compared to that over pure $\mathrm{TiO}_{2}$ and $\mathrm{ZnS}$. In particular, $1.2 \mathrm{mmol}$ of $\mathrm{H}_{2}$ gas was produced after $10 \mathrm{~h}$ when $0.5 \mathrm{~g}$ of a $5.0 \mathrm{wt} \% \mathrm{ZnS}$-loaded $\mathrm{TiO}_{2}$ composite was used. Recently, many studies began to focus their attention on bimetallic sulfides photocatalysts, such as CdZnS [16], CuZnS [17], ZnInS [18], and AgZnS [19]. These studies have been extended to trimetallic sulfide photocatalysts, such as CuAgInS [20], ZnCuCdS [21], CuInZnS [22], and AgGaInS [23]. On the other hand, most papers are based on metal sulfides loaded on the surface of $\mathrm{TiO}_{2}$ particles. Few studies have examined $\mathrm{TiO}_{2}$ nanoparticles loaded on the surface of large-sized metal sulfide particles.

This study focused on the CuS core material with a shorter band-gap of $1.56 \mathrm{eV}$ and a higher reduction potential [24] than those of pure $\mathrm{TiO}_{2}$. Cu materials are widely used as catalysts for methanol steam reforming because of their excellent redox properties despite vulnerable to water. The potential $\left(\mathrm{Cu}^{2+}+2 \mathrm{e}^{-}=\mathrm{Cu}^{0}, E^{\circ}=-0.224 \mathrm{~V}\right)$ is slightly lower than the conduction band $(-0.26 \mathrm{~V})$ of anatase $\mathrm{TiO}_{2}$ but is higher than the reduction potential of $\mathrm{H}^{+}\left(2 \mathrm{H}^{+}+2 \mathrm{e}^{-}=\right.$ $\mathrm{H}_{2}, E^{\circ}=-0.000 \mathrm{~V}$ ), which favors electron transfer from the conduction band of $\mathrm{TiO}_{2}$ to $\mathrm{Cu}^{2+}$, and the reduction of $\mathrm{H}^{+}$, thereby enhancing the photocatalytic $\mathrm{H}_{2}$-production activity $[25,26]$. In this study, CuS was synthesized by a hydrothermal method with sodium sulfate as the sulfur source. A Ti precursor at a high concentrated molar ratio was then coated on the surface of the CuS like a core-shell structure. The relationship between the spectroscopic properties and the catalytic performance for the hydrogen production over the core@shell-structured $\mathrm{CuS} @ \mathrm{TiO}_{2}$ was examined by X-ray diffraction (XRD), transmission electron microscopy (TEM), UV-visible absorption spectroscopy, Brunauer, Emmett, and Teller (BET) surface areas, cyclic voltammetry (CV), and zeta potential measurements using an electrophoresis measurement apparatus.

\section{Experimental}

2.1. Synthesis of CuS and Core@Shell-Structured CuS@TiO 2 . The $\mathrm{TiO}_{2}$, CuS, and core@shell-structured CuS@TiO ${ }_{2}$ photocatalysts were prepared using hydrothermal and impregnation methods, respectively. In the first step for $\mathrm{TiO}_{2}$, titanium tetra-isopropoxide (TTIP, 99.99\%, Junsei Chemical, Japan) as a titanium precursor was added dropwise to an aqueous solution and stirred homogeneously for $2 \mathrm{~h}$. The $\mathrm{pH}$ of the final solution was set to $\mathrm{pH}=3.0$ using acetic acid to induce mild hydrolysis, and the resulting solution was transferred to an autoclave for thermal treatment. The thermal treatment at $200^{\circ} \mathrm{C}$ was kept for $12 \mathrm{~h}$, and the resulting precipitates were obtained, washed with distilled water, and dried at $80^{\circ} \mathrm{C}$ for $24 \mathrm{~h}$. In the second step of $\mathrm{CuS}$ synthesis, $\mathrm{CuSO}_{4} \cdot 5 \mathrm{H}_{2} \mathrm{O}$ (99.99\%, Junsei Chemical, Japan) and $\mathrm{Na}_{2} \mathrm{~S}_{2} \mathrm{O}_{3} \cdot 5 \mathrm{H}_{2} \mathrm{O}$ (99.99\%, Junsei Chemical, Japan) were used as the $\mathrm{Cu}$ and $\mathrm{S}$ precursors to prepare the sol mixture, respectively. Copper sulfate and sodium sulfate were dissolved sequentially in distilled water and stirred to homogeneity for $2 \mathrm{~h}$. The final solution was transferred to an autoclave for thermal treatment. $\mathrm{Cu}$ ions were sulfurized during the thermal treatment at $180^{\circ} \mathrm{C}$ for $12 \mathrm{~h}$. The resulting precipitates were obtained, washed with distilled water, and dried at $80^{\circ} \mathrm{C}$ for $24 \mathrm{~h}$. Finally the dried powders were treated at $400^{\circ} \mathrm{C}$ for $4 \mathrm{~h}$ to obtain crystallized CuS. Finally, 4.0 and 5.0 moles of TTIP (titanium tetraisopropoxide, 99.99\%, Aldrich) for each 1.0 mole of $\mathrm{CuS}$ were added slowly to an ethanol solution containing the dispersed $\mathrm{CuS}$ particles during stirring to coat the $\mathrm{CuS}$ surface. The $\mathrm{pH}$ of the colloidal solution was kept at 4.0 , and the solution was stirred homogeneously for $18 \mathrm{~h}$. The final solution was evaporated at $80^{\circ} \mathrm{C}$ for $5 \mathrm{~h}$ and calcined at $400^{\circ} \mathrm{C}$ for $4 \mathrm{~h}$ to induce the anatase $\mathrm{TiO}_{2}$. Finally, three types of materials, $\mathrm{CuS}$ and the core@shell-structured 1CuS@4 $\mathrm{TiO}_{2}$ and $1 \mathrm{CuS} @ 5 \mathrm{TiO}_{2}$, were examined. Three samples of pure $\mathrm{TiO}_{2}$ (by hydrothermal method), $\mathrm{CuS}$, and physically mixed $\mathrm{TiO}_{2} / \mathrm{CuS}$ were also prepared for comparison.

\subsection{Characteristics of Synthesized CuS and Core@Shell-Struc-} tured $\mathrm{CuS@TiO}$. The synthesized CuS and core@shellstructured $\mathrm{CuS} @ \mathrm{TiO}_{2}$ photocatalysts were examined by XRD (X'Pert Pro MPD PANalytical 2-circle diffractometer) using nickel-filtered $\mathrm{CuK} \alpha$ radiation $(30 \mathrm{kV}$ and $30 \mathrm{~mA})$. The sizes and shapes of the $\mathrm{CuS}$ and core@shell-structured $\mathrm{CuS} @ \mathrm{TiO}_{2}$ photocatalysts were examined by TEM (JEOL 2000EX). The BET surface areas of catalysts were measured using a Belsorp II instrument. All the catalysts were degassed under vacuum at $150^{\circ} \mathrm{C}$ for 30 min before the BET surface measurements. The catalysts were measured through the nitrogen gas adsorption using a continuous flow method with a mixture of nitrogen and helium as the carrier gas. The UVvisible absorption spectra of CuS and core@shell-structured

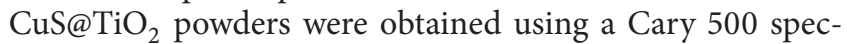
trometer with a reflectance sphere. The $\mathrm{CV}$ measurements of the $\mathrm{CuS}$ and core@shell-structured $\mathrm{CuS} @ \mathrm{TiO}_{2}$ pellets were obtained using a BAS 100B potentiostat at room temperature in $0.1 \mathrm{M} \mathrm{KCl}$ solution. A platinum wire as the counter electrode and $\mathrm{Ag} / \mathrm{AgCl}$ as the reference electrode were used. The zeta potential of CuS and core@shell-structured

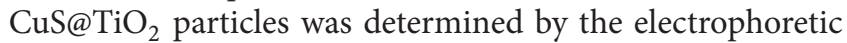
mobility using an electrophoresis measurement apparatus (ELS 8000, Otsuka Electronics, Japan) with a plate sample cell. Electrophoretic light scattering (ELS) was performed in reference beam mode using a laser light source of $670 \mathrm{~nm}$, a modular frequency of $250 \mathrm{~Hz}$, and a scattering angle of $15^{\circ}$. The standard error of the zeta potential, converted from the experimentally determined electrophoretic mobility, was typically $<1.5 \%$, and the percentage error was $<5 \%$. To measure the zeta potentials, $0.1 \mathrm{wt} \%$ of each sample was dispersed in deionized water, and the $\mathrm{pH}$ of the solution was adjusted with $\mathrm{HCl}$ or $\mathrm{NaOH}$. The relative molecular diameter size distributions of the various solutions were also measured using this equipment.

\subsection{Hydrogen Production from Photo-Splitting of Methanol/} Water over CuS and Core@Shell-Structured CuS@TiO 2 . Photo-splitting in methanol/water using CuS and core@shellstructured CuS@ $\mathrm{TiO}_{2}$ photocatalysts was carried out using a liquid photoreactor designed in house, as shown in Figure 1. 


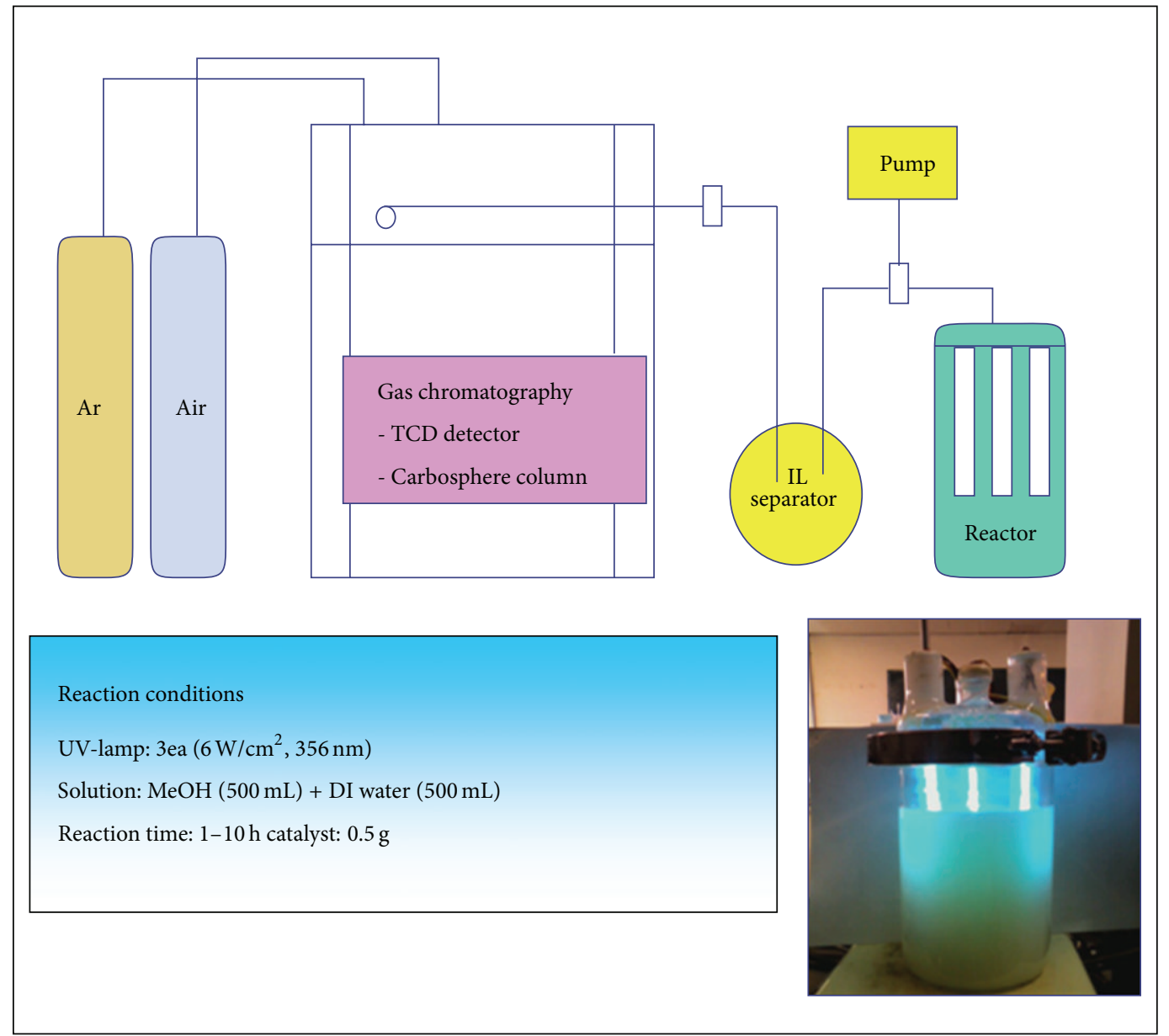

FIGURE 1: Apparatus of a liquid photoreactor for the methanol/water photo-splitting using $\mathrm{CuS}$ and core@shell-structured $\mathrm{CuS} @ \mathrm{TiO}_{2}$ photocatalysts.

For methanol/water photo-splitting, $0.5 \mathrm{~g}$ of a photocatalyst was added to $1.0 \mathrm{~L}$ distilled water in a $2.0 \mathrm{~L}$ Pyrex reactor. UV-lamps $\left(6 \times 3 \mathrm{~W} \mathrm{~cm}^{-2}=18 \mathrm{~W} \mathrm{~cm}^{-2}, 30 \mathrm{~cm}\right.$ length $\times 2.0 \mathrm{~cm}$ diameter; Shinan Co.) emitting radiation with a wavelength of $365 \mathrm{~nm}$ were used. Methanol/water photo-splitting was carried out for $10 \mathrm{~h}$ with constant stirring, and the level of hydrogen evolution was measured at $1 \mathrm{~h}$ intervals. The hydrogen gas $\left(\mathrm{H}_{2}\right)$ produced during methanol/water photosplitting was analyzed by TCD-type gas chromatography (GC, model DS 6200; Donam Instruments Inc., Republic of Korea). To determine the products and intermediates, the GC was connected directly to the methanol/water photo-splitting reactor. The following GC conditions were used: TCD detector; Carbosphere column (Alltech, Deerfield, IL, USA); and an injection, initial, final, and detector temperature of $413 \mathrm{~K}$, $393 \mathrm{~K}, 393 \mathrm{~K}$, and $423 \mathrm{~K}$, respectively.

\section{Results and Discussion}

3.1. Properties of Synthesized CuS and Core@Shell-Structured $\mathrm{CuS@TiO}$. Figure 2 shows XRD patterns of the $\mathrm{TiO}_{2}, \mathrm{CuS}$,

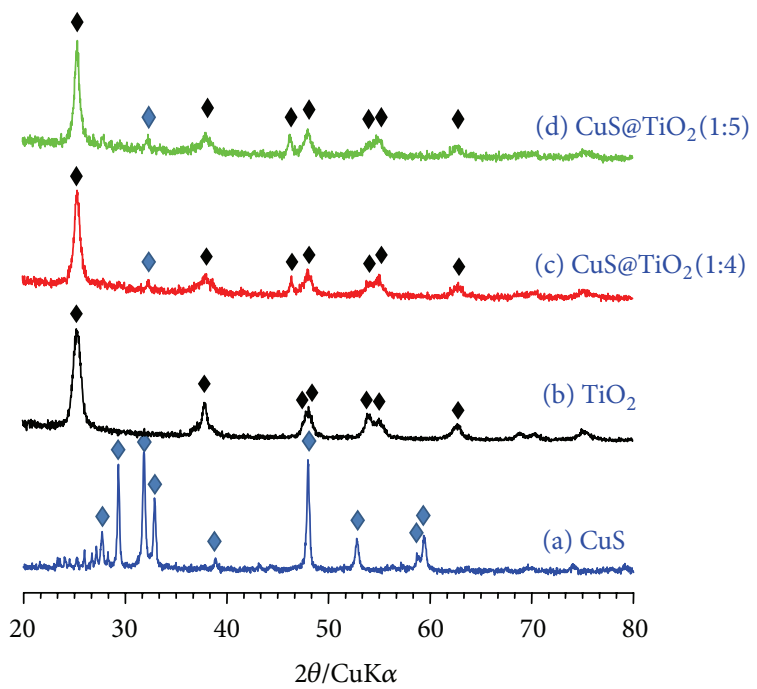

- $\mathrm{TiO}_{2}$ (anatase)

$\diamond \mathrm{CuS}$

FIGURE 2: XRD patterns of the CuS and CuS@ $\mathrm{TiO}_{2}$ photocatalysts. 


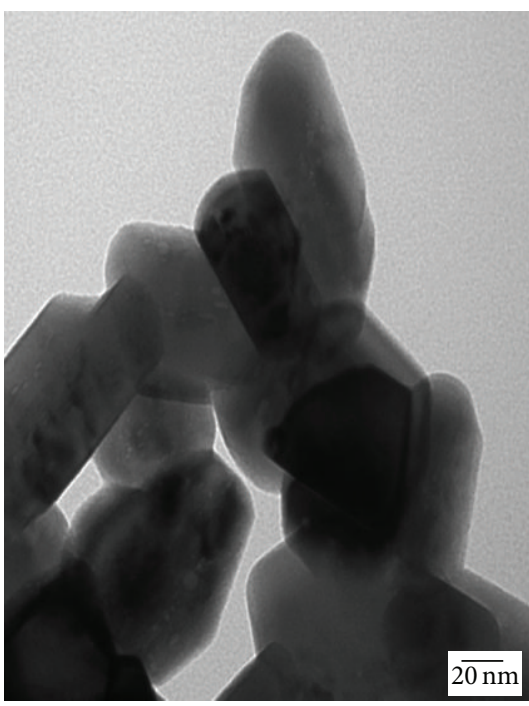

(a) $\mathrm{CuS}$

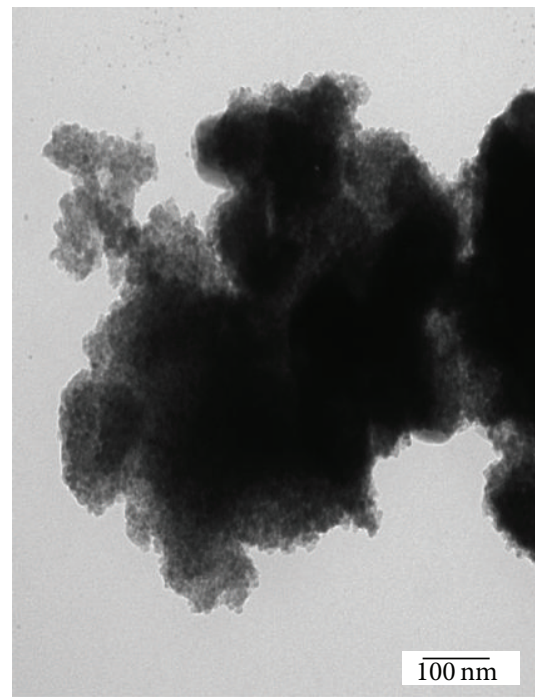

(c) $\mathrm{CuS@TiO} 2(1: 4)$

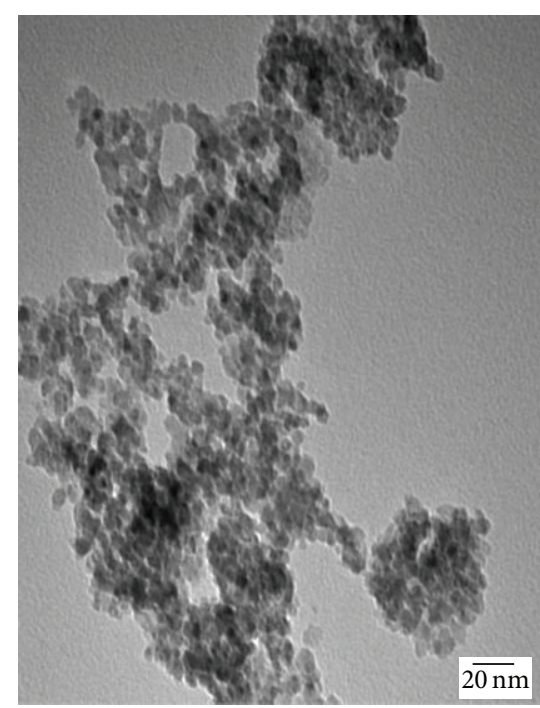

(b) $\mathrm{TiO}_{2}$

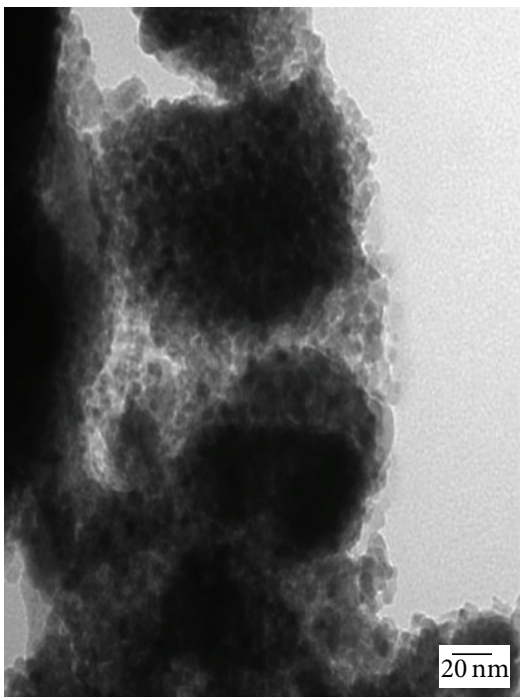

(d) $\mathrm{CuS@TiO} 2(1: 5)$

Figure 3: TEM images of the $\mathrm{CuS}$ and $\mathrm{CuS@TiO}$, photocatalysts.

and $\mathrm{CuS@TiO} 2$ photocatalysts. All the peaks in $\mathrm{CuS}$ were indexed to the hexagonal phase $\mathrm{CuS}$ (P63/mmc space, cell constants $a=3.8 \AA, b=3.8 \AA$, and $c=16.43 \AA$; JCPDS Card no. 02-0820). The XRD patterns showed the main peaks at $26.75,27.51,29.36,31.82,33.03,38.96,43.04,44.60$, $52.88,59.18,63.69,67.86,69.58,74.00$, and $79.08^{\circ} 2 \theta$, which were assigned to the (100), (101), (102), (103), (006), (105), (106), (008), (110), (114), (116), (1010), (0012), (207), (208), and (213) planes, respectively. In the case of $\mathrm{CuS@TiO}$, the peaks for crystalline $\mathrm{CuS}$ almost disappeared except for a very small peak at $33.03^{\circ} 2 \theta(006)$. This result coincides with the fact that in general if the core-shell structure formed completely in a core-shell material, the XRD peaks for the core do not appear; only the diffraction patterns for the shell are observed [27]. Otherwise, the XRD patterns for crystalline $\mathrm{TiO}_{2}$ (anatase, tetragonal crystal system, I41/amd space, JCPDS Card no. 02-0387) in CuS@ TiO 2 were observed at $25.35,37.93,48.10,53.89,55.30,68.99,70.18$, and $75.37^{\circ}$ $2 \theta$, which were assigned to the (101), (004), (200), (105), (211), (116), (220), and (215) planes, respectively. The locations were the same as the hydrothermally prepared pure $\mathrm{TiO}_{2}$ in (b). The peaks in $\mathrm{CuS} @ \mathrm{TiO}_{2}$ were slightly larger according to the loaded $\mathrm{Ti}$ concentration. The XRD peak intensities that were assigned to anatase $\mathrm{TiO}_{2}$ in $1 \mathrm{CuS} @ 5 \mathrm{TiO}_{2}$ were slightly sharper than those of $\mathrm{CuS@TiO}$, loaded with 4.0 mol-concentrated Ti. Generally, the line widths of the XRD peaks were broad, which indicated a smaller crystallite size. The Scherrer equation, $t=0.9 \lambda / \beta \cos \theta$, where $\lambda$ is the wavelength of incident X-rays, $\beta$ is the full width at half maximum (FWHM) in radians, and $\theta$ is the diffraction angle, 


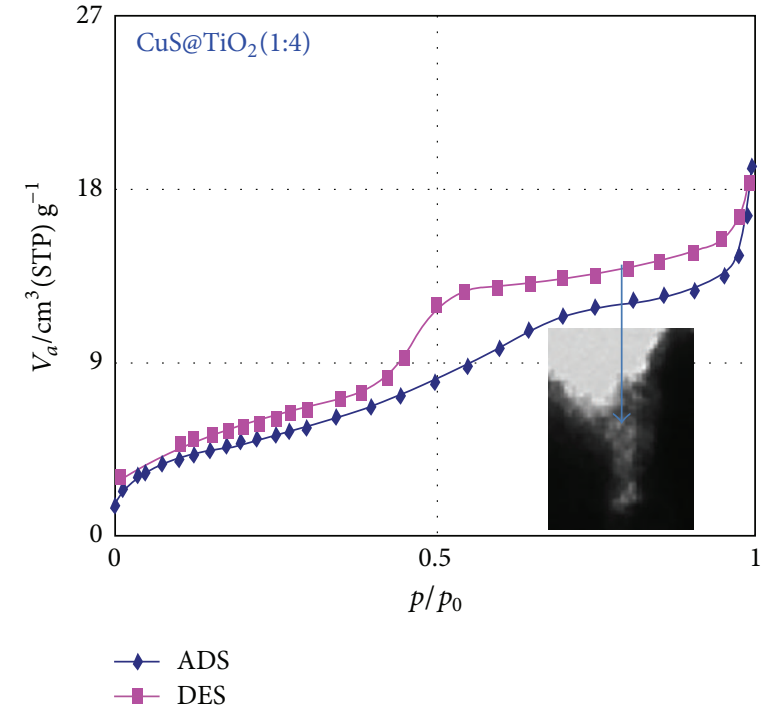

(a)

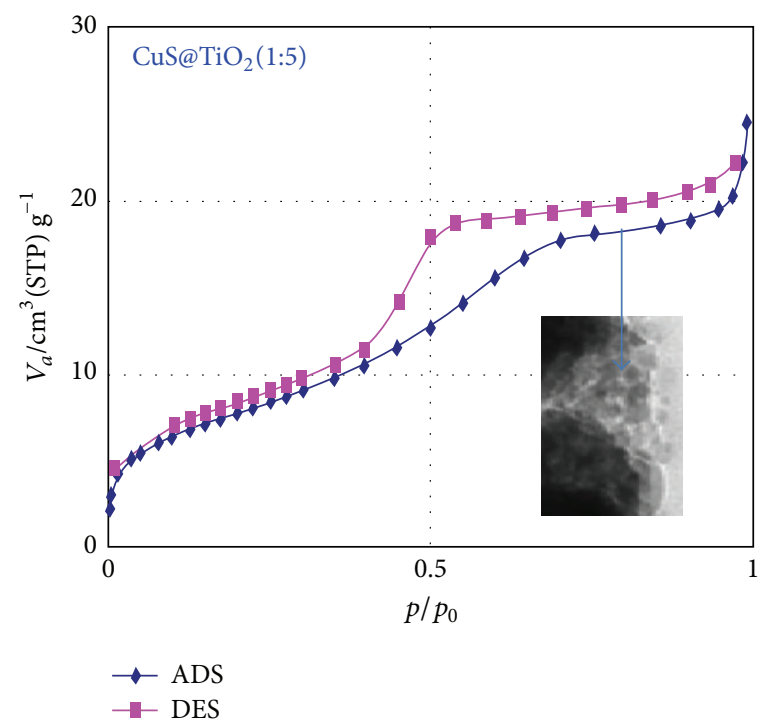

(b)

\begin{tabular}{|c|c|c|}
\hline & $\mathrm{CuS@TiO}_{2}(1: 4)$ & $\mathrm{CuS@TiO}_{2}(1: 5)$ \\
\hline Surface area $\left(\mathrm{m}^{2} \mathrm{~g}^{-1}\right)$ & 17.88 & 27.966 \\
\hline Total pore volume $\left(\mathrm{cm}^{3} \mathrm{~g}^{-1}\right)$ & 0.02973 & 0.037988 \\
\hline Average pore diameter $(\mathrm{nm})$ & 6.651 & 5.4334 \\
\hline
\end{tabular}

(c)

FIgURE 4: Adsorption-desorption isotherm curves of $\mathrm{N}_{2}$ at $77 \mathrm{~K}$ for the core@shell-structured $\mathrm{CuS@TiO}$.

was used to determine the crystallite size. The loaded $\mathrm{TiO}_{2}$ crystallite sizes of $1 \mathrm{CuS} @ 4 \mathrm{TiO}_{2}$ and $1 \mathrm{CuS} @ 5 \mathrm{TiO}_{2}$ based on the $25.35^{\circ} 2 \theta$ peak were 17.50 and $17.90 \mathrm{~nm}$, respectively.

Figure 3 shows TEM images of the $\mathrm{CuS}$ and $\mathrm{CuS@TiO} 2$ powders. Rectangular-shaped particles with $100 \mathrm{~nm}$ long and $60 \mathrm{~nm}$ wide sides were observed in the $\mathrm{CuS}$ sample, and $10 \mathrm{~nm}$ sized $\mathrm{TiO}_{2}$ particles were also observed in $\mathrm{TiO}_{2}$ samples. Here, the nanosized $\mathrm{TiO}_{2}$ particles were synthesized hydrothermally for comparison. Interestingly, the huge $\mathrm{CuS}$ particles were surrounded by nanosized $\mathrm{TiO}_{2}$ particles with high concentrations (4 5 moles compared to 1 mole of core $\mathrm{CuS})$. This is in good agreement with the XRD patterns. This is a reliable result in that, when the loaded $\mathrm{TiO}_{2}$ amounts increased, the shell composed of $\mathrm{TiO}_{2}$ particles was thicker.

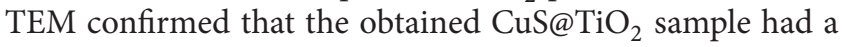
core@shell structure.

Figure 4 shows the adsorption-desorption isotherm curves of $\mathrm{N}_{2}$ at $77 \mathrm{~K}$ for the fresh powder samples and core@shell-structured CuS@ $\mathrm{TiO}_{2}$. The isotherms belonged to the IV type in the IUPAC classification [28]. Generally, this hysteresis slope has been observed in the presence of large mesopores. Here, the mesopores are considered to be bulk pores formed between $\mathrm{TiO}_{2}$ particles in the shell. This suggests that the reaction of the catalyst with a high surface area facilitates adsorption, which can improve the catalytic activity. Therefore, it is expected that the methanol or water molecules are adsorbed more easily on the surfaces of the core@shell-structured $\mathrm{CuS@} \mathrm{TiO}_{2}$ than those of pure $\mathrm{TiO}_{2}$ or $\mathrm{CuS}$ particles during methanol/water photo-splitting. The surface area increased from 17.88 to $27.97 \mathrm{~m}^{2} \mathrm{~g}^{-1}$ according to the change in $\mathrm{TiO}_{2}$ concentration from 4.0 to $5.0 \mathrm{~mol}$. Generally, the specific surface area increases with decreasing particle size. Here, the loaded $\mathrm{TiO}_{2}$ particle sizes in the two samples were similar. Therefore, the surface area in this study possibly depends on the bulk pores formed by aggregation between the $\mathrm{TiO}_{2}$ particles in the shell. The total bulk-pore volumes increased from 0.029 ( $4 \mathrm{~mol} \mathrm{TiO}_{2}$ loading) to 0.038 (5 $\mathrm{mol} \mathrm{TiO}_{2}$ loading) $\mathrm{cm}^{3} \mathrm{~g}^{-1}$. Eventually, the specific surface area increased with increasing pore volume.

Figure 5 shows the UV-visible absorption spectra of the CuS and core@shell-structured $\mathrm{CuS@TiO}$. powders. The absorption edges of $\mathrm{Ti}^{4+}$ and $\mathrm{Cu}^{2+}$ with octahedral symmetries normally appear at a maximum of approximately 300 and $700 \mathrm{~nm}$ in pure $\mathrm{TiO}_{2}$ and CuS, respectively $[29,30]$. The band gap in a semiconductor material is closely related to the wavelength range absorbed, where the band gap decreases with increasing absorption wavelength. Consequently, a material with a narrow band gap can be extended readily to utilize visible light, whereas a narrow band gap can reduce photocatalytic activity by increasing the recombination rate 


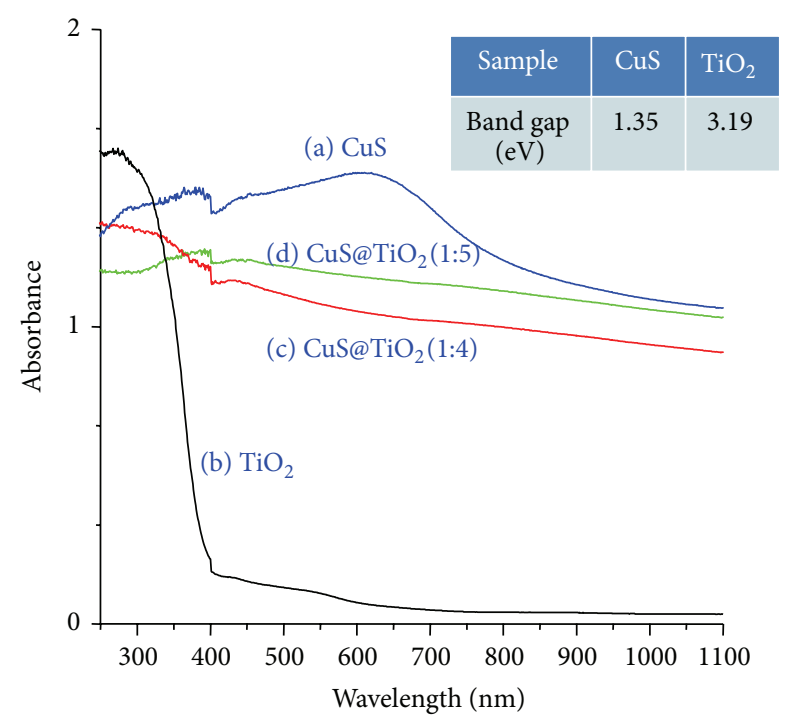

FIGURE 5: UV-visible absorption spectra of the CuS and core@shellstructured CuS@ $\mathrm{TiO}_{2}$ powders.

between the electrons and holes. Based on the Tauc equation [31], the band gaps obtained by extrapolation at the crosssection point of the two tangents were approximately 1.35 and $3.19 \mathrm{eV}$ for pure $\mathrm{CuS}$ and $\mathrm{TiO}_{2}$, respectively.

Figure 6 presents the $\mathrm{CV}$ measurements of $\mathrm{CuS}$ and the core@shell-structured $\mathrm{CuS@TiO}$, indicating high dependence on the analytic conditions being studied, which must be redox active within the experimental potential window. A reversible wave that provides the following information is desirable: reversible reactions will show a ratio of the peak currents passed at reduction $\left(E_{\mathrm{pc}}\right)$ and oxidation $\left(E_{\mathrm{pa}}\right)$. When such reversible peaks are observed, thermodynamic information in the form of a half cell potential $E_{1 / 2}^{\circ}\left(E_{\mathrm{pc}}+\right.$ $\left.E_{\mathrm{pa}} / 2\right)$ can be determined. In particular, when the waves are semireversible, such as when $E_{\mathrm{pa}} / E_{\mathrm{pc}} \geq 1$, it can be possible to induce even more information, particularly in kinetic processes. Recently, some studies reported a useful equation that can determine the energy levels of the HOMO and LUMO using a CV method [32]. In the synthesized $\mathrm{CuS}$, the $\mathrm{Cu}(\mathrm{II}) \rightarrow \mathrm{Cu}(0)$ redox process appeared to be a reversible reaction, and the absolute potential in the reduction $\left(E_{\mathrm{pc}}\right)$ was observed at $-0.732 \mathrm{~V}$. The onset potentials in the core@shell-structured $\mathrm{CuS} @ \mathrm{TiO}_{2}$ samples might be used to determine the thermodynamic $E_{1 / 2}^{\circ}$ as -1.255 and $-2.59 \mathrm{~V}$ in $1 \mathrm{CuS} @ 4 \mathrm{TiO}_{2}$ and $1 \mathrm{CuS} @ 5 \mathrm{TiO}_{2}$, respectively. The $\mathrm{CV}$ curves were observed at two locations, and there might be two factors from $\mathrm{TiO}_{2}$ (front) and $\mathrm{CuS}$ (back), -1.79 and $-0.712 \mathrm{~V}$, respectively. Therefore, the corresponding LUMO energy levels were calculated to be -3.65 (for $\mathrm{CuS}$ ), -3.12 (for

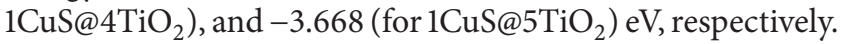

Figure 7 summarizes the hydrogen evolution from methanol/water photo-splitting over the $\mathrm{CuS}, \mathrm{TiO}_{2}$, and two types of core@shell-structured CuS@ $\mathrm{TiO}_{2}$ photocatalysts in a batch-type liquid photosystem, and the catalytic performance of a physically mixed $\mathrm{CuS}+\mathrm{TiO}_{2}$ sample was also evaluated for comparison. The catalytic activities of the core@shellstructured CuS@ $\mathrm{TiO}_{2}$ photocatalysts were enhanced considerably compared to the pure $\mathrm{CuS}$ or $\mathrm{TiO}_{2}$. In Figure 7(a), a very small amount of hydrogen was collected over $\mathrm{CuS}$ $(0.2 \mathrm{mmol})$ and $\mathrm{TiO}_{2}(0.09 \mathrm{mmol})$ after methanol/water photo-splitting for $10 \mathrm{~h}$. A significant amount of hydrogen gas was collected over CuS@ $\mathrm{TiO}_{2}$, and the amount of hydrogen produced reached $1.9 \mathrm{mmol}$ over $0.5 \mathrm{~g} 1 \mathrm{CuS} @ 4 \mathrm{TiO}_{2}$. On the other hand, the amount produced was significantly lower on the core@shell-structured 1CuS@5 $\mathrm{TiO}_{2}$ catalyst with higher $\mathrm{Ti}$ incorporation. Here, $\mathrm{CuS}$ absorbs longer wavelengths easily, but recombination between the excited electrons and the holes also causes rapid catalytic deactivation. In contrast, the core@shell-structured CuS@ $\mathrm{TiO}_{2}$ has stronger oxidationreduction ability than pure $\mathrm{CuS}$. Here, the $\mathrm{CuS}$ core acts as a good electron collector excited from $\mathrm{TiO}_{2}$ and transporter, resulting in the retardation of electron-hole recombination, leading to an increase in photocatalytic performance. On the other hand, the collected hydrogen did not increase significantly over the physically mixed $\mathrm{CuS}+\mathrm{TiO}_{2}$ sample. The catalytic performance of methanol/water destruction over the core@shell-structured $1 \mathrm{CuS} @ 4 \mathrm{TiO}_{2}$ was enhanced more under the alkali electrolytes solution, as shown in Figure $7(\mathrm{~b})$. When $\mathrm{OH}^{-}$ions are present in the alkali solution, the subsequent reaction occurs: $\mathrm{OH}^{-}+$hole $\rightarrow{ }^{\circ} \mathrm{OH}$ in the valence band. Therefore, a large number of $\mathrm{OH}$ radicals are generated in the alkali solution, resulting in an increase in hydrogen evolution. Hydrogen production was increased dramatically in the alkali solution by generating more $\mathrm{OH}$ ions, reaching up to $8.0 \mathrm{mmol}$ after $10 \mathrm{~h}$ in a $\mathrm{KOH}(\mathrm{pH}=$ 11) solution. In an acidic solution, however, the level of production was decreased due to $\mathrm{SO}_{4}{ }^{2-}$ ions formed after the reaction. The $\mathrm{S}$ ions inside the $\mathrm{CuS}$ catalyst appear to dissolve in the acidic solution, followed by a reaction with $\mathrm{O}$ ions in water to form $\mathrm{SO}_{4}{ }^{2-}$ ions. Eventually, the sulfate ions combine with the hydrogen ions generated during the methanol/water photo-splitting process, which occurs during the formation of $\mathrm{H}_{2} \mathrm{SO}_{4}$.

Figure 8 shows the influence of $\mathrm{pH}$ on the zeta potential distribution in the $\mathrm{CuS}, \mathrm{TiO}_{2}$, and two types of core@shellstructured $\mathrm{CuS} @ \mathrm{TiO}_{2}$. The adjacent table summarizes the aggregated particle sizes in the aqueous solution. The zeta potential of the 1CuS@4 $4 \mathrm{TiO}_{2}$ suspensions decreased significantly with increasing $\mathrm{pH}$. The surface charges in all samples changed from a positive value in an acidic solution to a larger negative value in an alkali solution. The isoelectric points, meaning the large aggregation of particles, were different: 5.8 , 7.9, 7.0, and 7.7 for $\mathrm{CuS}, \mathrm{TiO}_{2}, 1 \mathrm{CuS} @ 4 \mathrm{TiO}_{2}$, and $1 \mathrm{CuS} @ 5 \mathrm{TiO}_{2}$, respectively. At $\mathrm{pH}=11.0$, the surface charges in all samples showed the highest absolute value. This suggests that the colloidal samples were stable [33] with high mobility, which is closely related to the reaction sites over the photocatalyst surface. This result matches the results in Figure 6 well.

The CV curves, UV-visible absorption spectra, and their photocatalytic performance suggest a photocatalysis model over the core@shell-structured $\mathrm{CuS@TiO}$, as shown in Scheme 1. The $\mathrm{TiO}_{2}$ shells covered the core CuS completely, which means that the electrons on the valence band of 


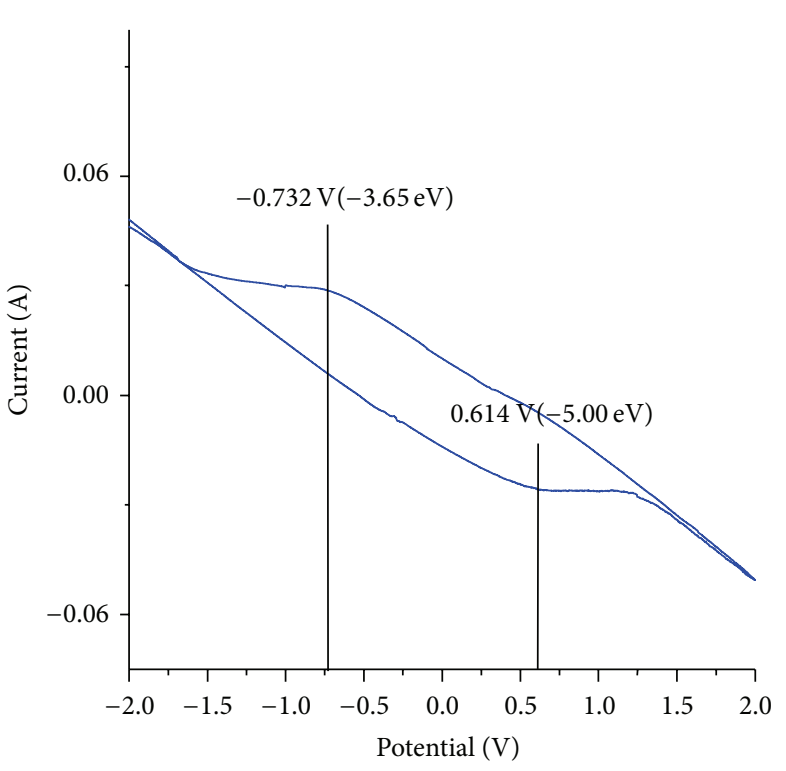

(a) $\mathrm{CuS}$

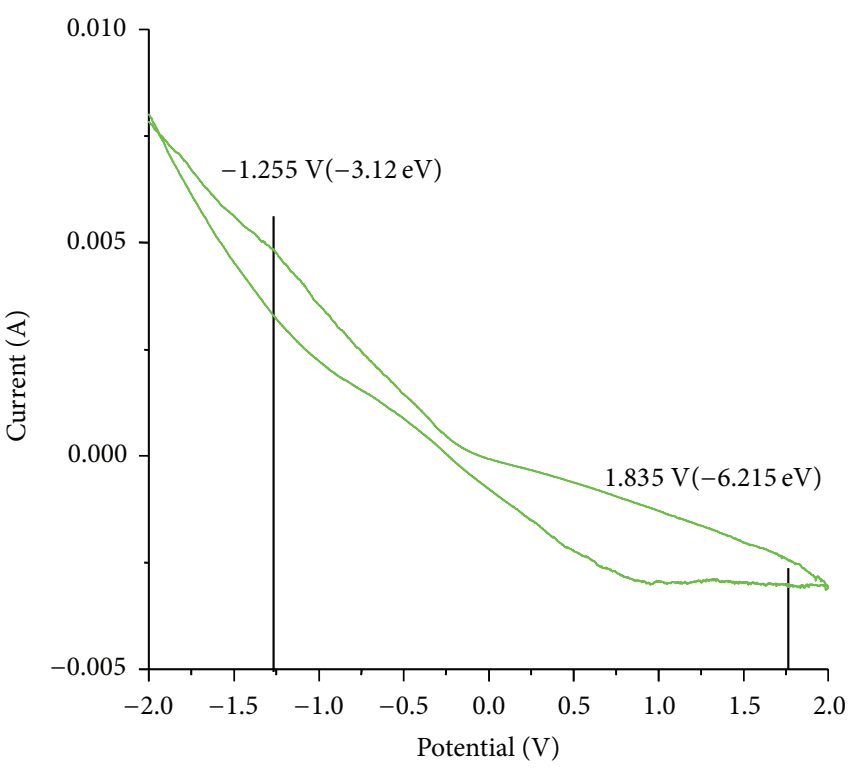

(b) $\mathrm{CuS@TiO} 2(1: 4)$

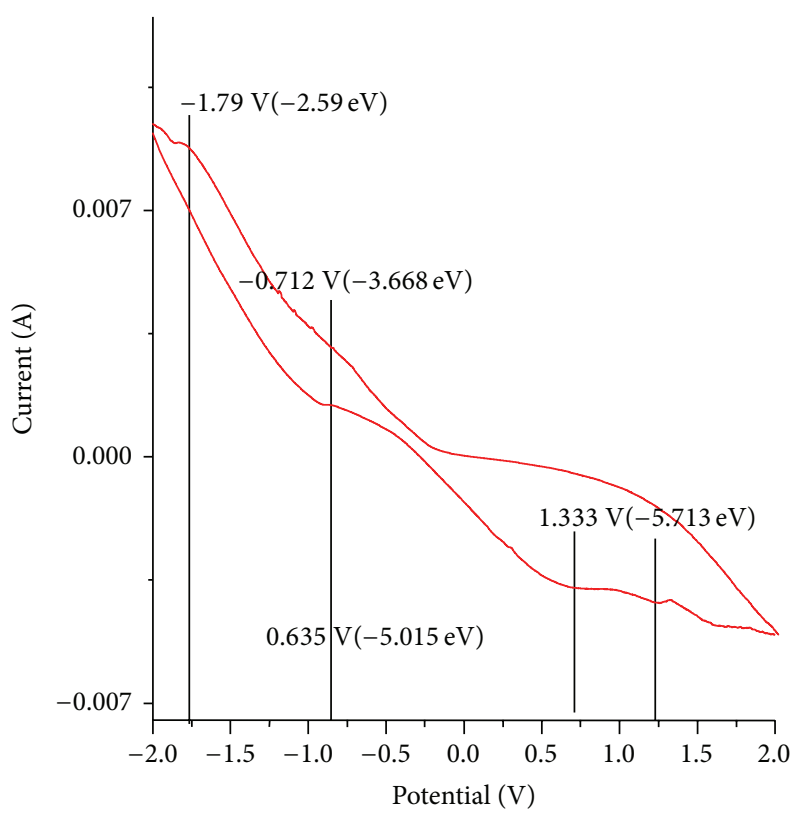

(c) $\mathrm{CuS@TiO} 2(1: 5)$

FIGURE 6: Cyclic voltammetry for the CuS and core@shell-structured CuS@TiO 2 .

$\mathrm{TiO}_{2}$ will be transferred to the conduction band. The excited electrons are moved to the valence band in $\mathrm{CuS}$ because of its higher reduction potential than $\mathrm{TiO}_{2}$. In this study the core $\mathrm{CuS}$ acted as a good electron collector and transporter, similar to reduced graphene oxide reported in another paper [34]. Therefore, the recombination of electrons and holes was reduced, and finally more $\mathrm{OH}$ radicals were generated easily at the holes in the valence band of $\mathrm{TiO}_{2}$. Radicals with strong oxidative power attack $\mathrm{CH}_{3} \mathrm{OH}$ molecules, and $\mathrm{CO}_{2}, \mathrm{H}_{2}$, and $\mathrm{H}_{2} \mathrm{O}$ are produced by the complete oxidation of methanol. In addition, if the core CuS also absorbs the radiation (if it does not have a complete core@shell structure), the electrons would be excited more easily from the valence band of CuS. Overall, the catalytic activity of $\mathrm{CuS@TiO}$ is performed more effectively in the methanol/water photosplitting reaction. This also means that the electrons excited from the valence band over $\mathrm{CuS@TiO}$, recombine slowly with the holes during photocatalysis. Therefore, the hole effect at the valence band continues for a longer time than those in pure $\mathrm{CuS}$ or $\mathrm{TiO}_{2}$. In addition, according to the UVvisible spectra, the $\mathrm{CuS@TiO}$ samples exhibited enhanced absorbance over the entire visible-light region. Therefore, the $\mathrm{CuS}$ core can also absorb visible radiation compared to the $\mathrm{TiO}_{2}$ shell, which can only absorb UV light. Consequently, 

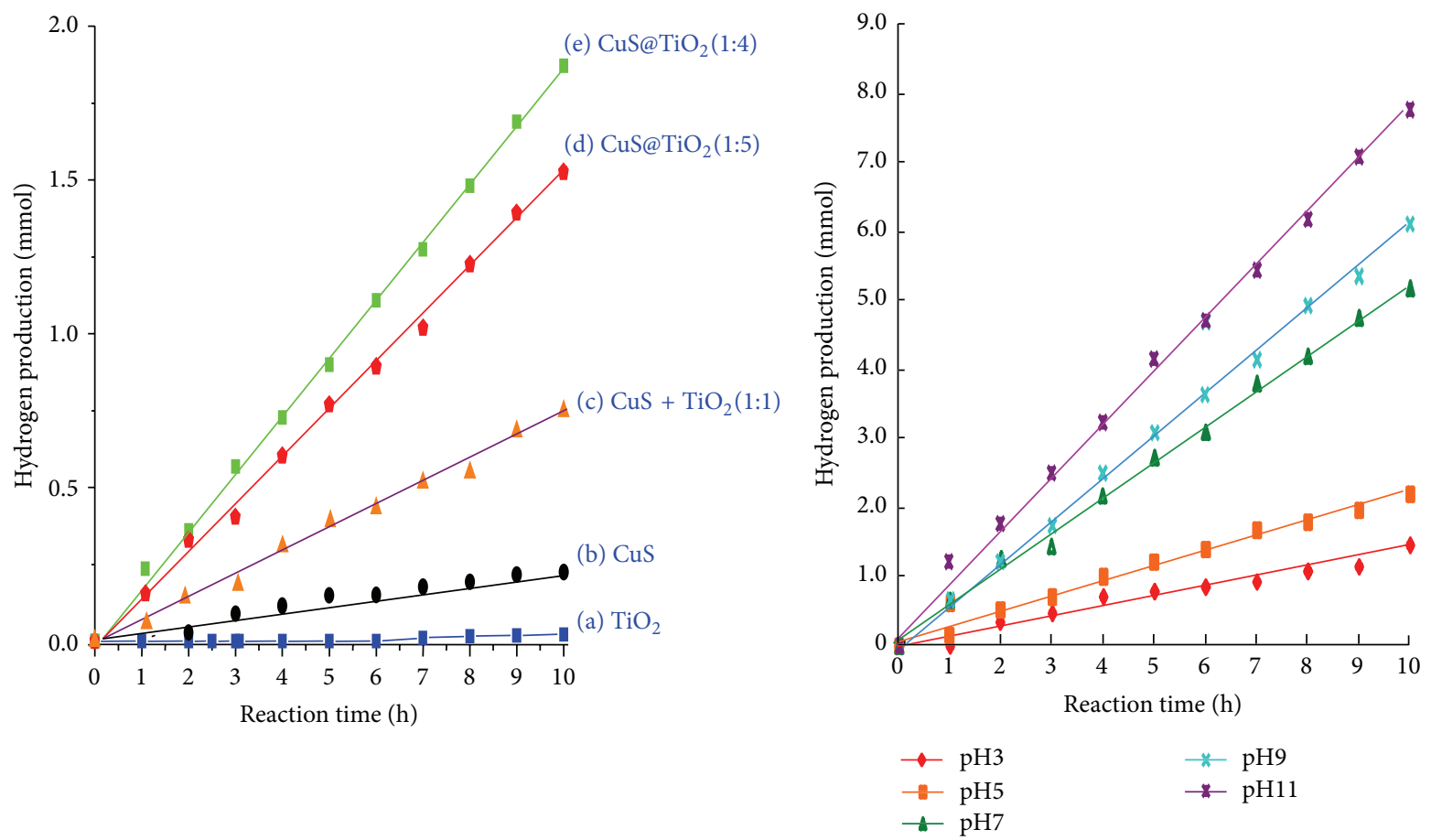

(a)

(b)

Figure 7: Evolution of $\mathrm{H}_{2}$ from methanol/water photo-splitting over the $\mathrm{CuS}, \mathrm{TiO}_{2}$, and two types of core@shell-structured $\mathrm{CuS} @ \mathrm{TiO}_{2}$ photocatalysts in a batch-type liquid photosystem. (a) Hydrogen production according to the catalysts and (b) hydrogen production according

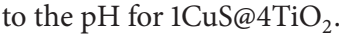

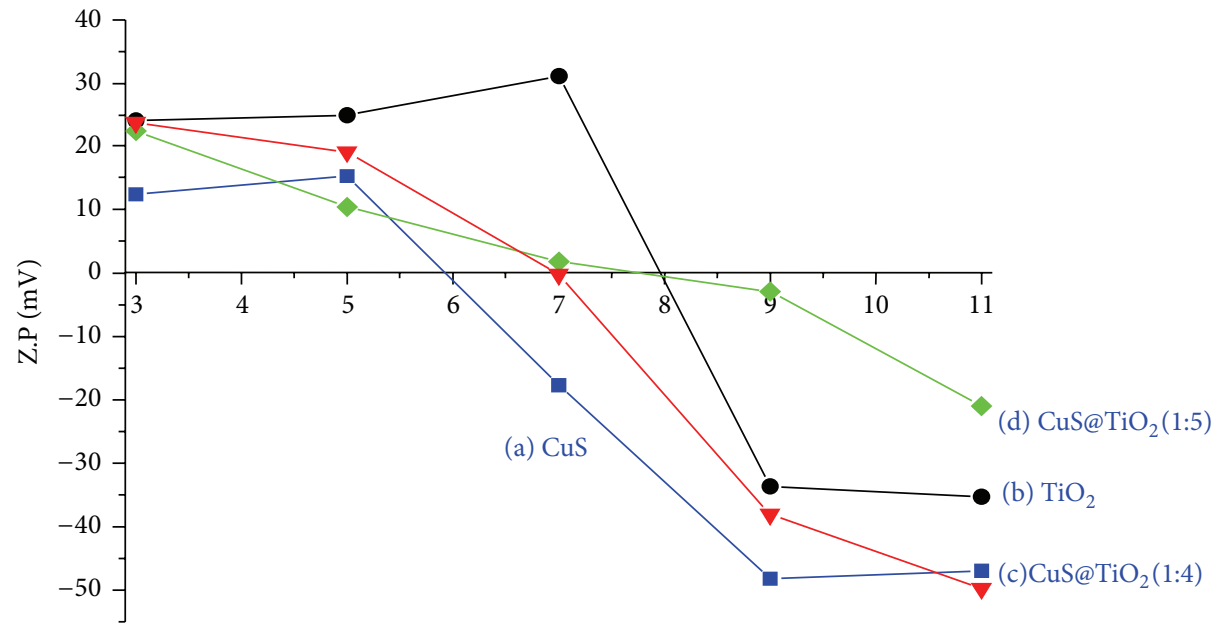

\begin{tabular}{|c|c|c|c|c|c|c|c|c|}
\hline & \multicolumn{2}{|c|}{$(\mathrm{a}) \mathrm{CuS}$} & \multicolumn{2}{|c|}{$(\mathrm{b}) \mathrm{TiO}_{2}$} & \multicolumn{2}{c|}{$(\mathrm{c}){\mathrm{CuS} @ \mathrm{TiO}_{2}(1: 4)}$} & \multicolumn{2}{c|}{$(\mathrm{d}) \mathrm{CuS}_{2}(1: 5)$} \\
\hline $\mathrm{pH}$ & $\begin{array}{c}\text { Zeta } \\
\text { potential } \\
(\mathrm{mV})\end{array}$ & $\begin{array}{c}\text { Mobility } \\
\left(\mathrm{cm}^{2} / \mathrm{Vs}\right)\end{array}$ & $\begin{array}{c}\text { Zeta } \\
\text { potential } \\
(\mathrm{mV})\end{array}$ & $\begin{array}{c}\text { Mobility } \\
\left(\mathrm{cm}^{2} / \mathrm{Vs}\right)\end{array}$ & $\begin{array}{c}\text { Zeta potential } \\
(\mathrm{mV})\end{array}$ & $\begin{array}{c}\text { Mobility } \\
\left(\mathrm{cm}^{2} / \mathrm{Vs}\right)\end{array}$ & $\begin{array}{c}\text { Zeta } \\
\text { potential } \\
(\mathrm{mV})\end{array}$ & $\begin{array}{c}\text { Mobility } \\
\left(\mathrm{cm}^{2} / \mathrm{Vs}\right)\end{array}$ \\
\hline 3 & 12.47 & $9.739 e(-4)$ & 24.06 & $1.944 e(-4)$ & 23.76 & $1.853 e(-4)$ & 22.42 & $1.749 e(-4)$ \\
\hline 5 & 15.34 & $1.199 e(-5)$ & 24.89 & $1.944 e(-4)$ & 19.13 & $1.492 e(-4)$ & 10.5 & $8.189 e(-5)$ \\
\hline 7 & -17.65 & $-1.377 e(-4)$ & 31.13 & $4.478 e(-4)$ & -0.23 & $-1.802 e(-6)$ & 1.84 & $1.435 e(-5)$ \\
\hline 9 & -48.24 & $-3.775 e(-4)$ & -33.61 & $-2.752 e(-4)$ & -38.08 & $-2.970 e(-4)$ & -2.88 & $-2.246 e(-4)$ \\
\hline 11 & -47.01 & $-3.673 e(-4)$ & -35.29 & $-2.752 e(-4)$ & -49.78 & $-3.887 e(-4)$ & -20.94 & $-1.636 e(-4)$ \\
\hline
\end{tabular}

Figure 8: Zeta potential distributions of the $\mathrm{CuS}, \mathrm{TiO}_{2}$, and two types of core@shell-structured $\mathrm{CuS@TiO}$ according to the pH. 


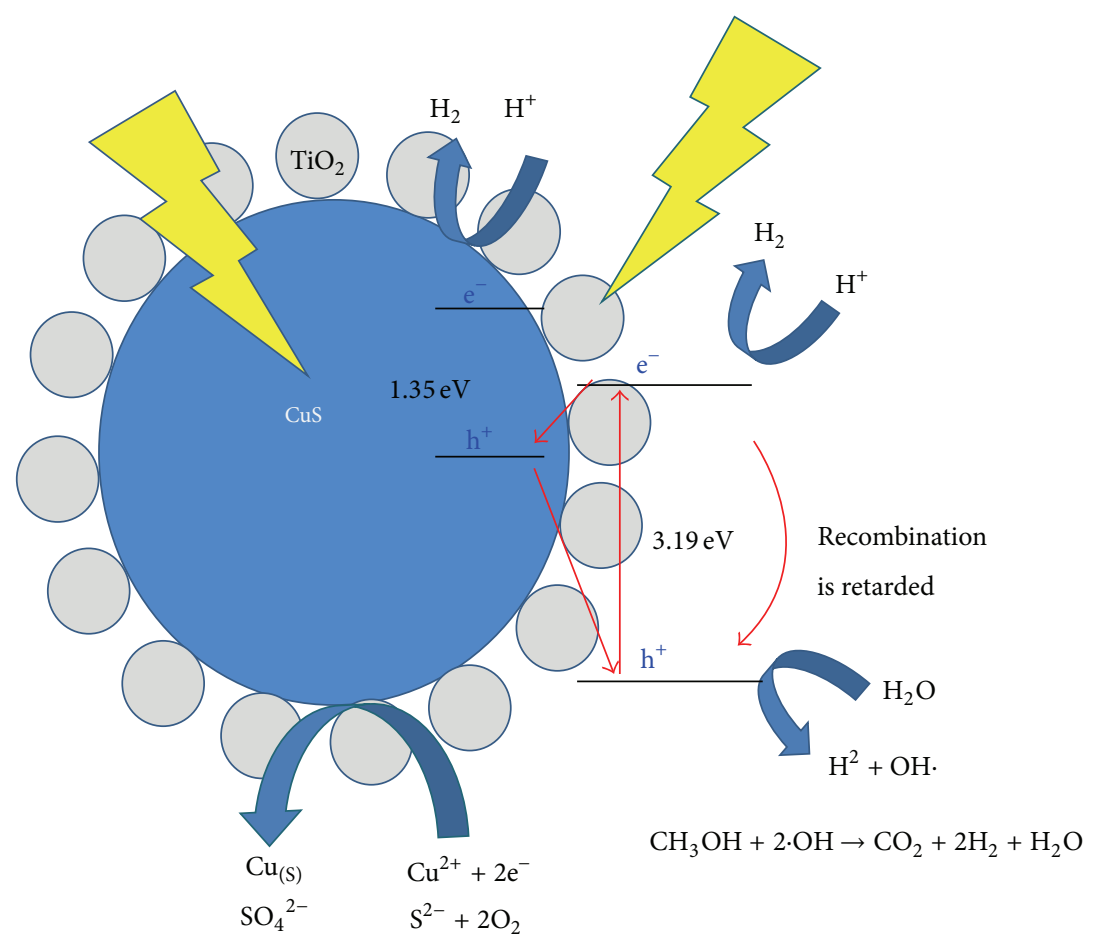

Scheme 1: Supposed photocatalysis model over the core@shell-structured CuS@ $\mathrm{TiO}_{2}$.

the photocatalytic activity is enhanced over the core@shellstructured CuS@TiO, photocatalysts.

\section{Conclusions}

Core@shell-structured CuS@TiO 2 was synthesized using hydrothermal/impregnation methods. Based on the UVvisible absorption and CV results, the band gap of the pure $\mathrm{CuS}$ was estimated to be approximately $1.35 \mathrm{eV}$, respectively, and the corresponding LUMO energy level was $-3.65 \mathrm{eV}$. ELS showed that the core@shell-structured 1CuS@4 $\mathrm{TiO}_{2}$ particles were stable in an alkali solution. A significant amount of hydrogen gas was collected over $0.5 \mathrm{~g}$ of the core@shell-structured 1CuS@4 $\mathrm{TiO}_{2}$ photocatalyst, and the amount reached $1.9 \mathrm{mmol}$ with a maximum yield of $8.0 \mathrm{mmol}$ after $10 \mathrm{~h}$ in a $\mathrm{KOH}$ solution. This was due most likely to the slower recombination between the electrons and a hole, which enables higher catalytic performance over

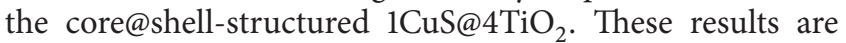
expected to play a significant role in the development of new photocatalysts with a core@shell structure for dramatic hydrogen production.

\section{Acknowledgment}

This work was supported by the New \& Renewable Energy of the Korea Institute of Energy Technology Evaluation and Planning (KETEP) Grant funded by the Korea government Ministry of Knowledge Economy (no. 20103020050040).

\section{References}

[1] S. Xu, A. J. Du, J. Liu, J. Ng, and D. D. Sun, "Highly efficient $\mathrm{CuO}$ incorporated $\mathrm{TiO}_{2}$ nanotube photocatalyst for hydrogen production from water," International Journal of Hydrogen Energy, vol. 36, no. 11, pp. 6560-6568, 2011.

[2] S. Xu, J. Ng, X. Zhang, H. Bai, and D. D. Sun, "Fabrication and comparison of highly efficient $\mathrm{Cu}$ incorporated $\mathrm{TiO}_{2}$ photocatalyst for hydrogen generation from water," International Journal of Hydrogen Energy, vol. 35, no. 11, pp. 5254-5261, 2010.

[3] S. Onsuratoom, T. Puangpetch, and S. Chavadej, "Comparative investigation of hydrogen production over $\mathrm{Ag}-, \mathrm{Ni}$-, and $\mathrm{Cu}-$ loaded mesoporous-assembled $\mathrm{TiO}_{2}-\mathrm{ZrO}_{2}$ mixed oxide nanocrystal photocatalysts," Chemical Engineering Journal, vol. 173, no. 2, pp. 667-675, 2011.

[4] Q. Wang, N. An, Y. Bai et al., "High photocatalytic hydrogen production from methanol aqueous solution using the photocatalysts $\mathrm{CuS} / \mathrm{TiO}_{2}$," International Journal of Hydrogen Energy, vol. 38, no. 25, pp. 10739-10745, 2013.

[5] T. Miwa, S. Kaneco, H. Katsumata et al., "Photocatalytic hydrogen production from aqueous methanol solution with $\mathrm{CuO}$ / $\mathrm{Al}_{2} \mathrm{O}_{3} / \mathrm{TiO}_{2}$ nanocomposite," International Journal of Hydrogen Energy, vol. 35, no. 13, pp. 6554-6560, 2010.

[6] M. Zhong, J. Shi, W. Zhang, H. Han, and C. Li, "Charge recombination reduction in dye-sensitized solar cells by depositing ultrapure $\mathrm{TiO}_{2}$ nanoparticles on "inert" $\mathrm{BaTiO}_{3}$ films," Materials Science and Engineering B, vol. 176, no. 14, pp. 1115-1122, 2011.

[7] L. S. Yoong, F. K. Chong, and B. K. Dutta, "Development of copper-doped $\mathrm{TiO}_{2}$ photocatalyst for hydrogen production under visible light," Energy, vol. 34, no. 10, pp. 1652-1661, 2009.

[8] A. H. Gordillo, F. Tzompantzi, and R. Gómez, "An efficient ZnSUV photocatalysts generated in situ from $\mathrm{ZnS}(\mathrm{en})_{0.5}$ hybrid 
during the $\mathrm{H}_{2}$ production in methanol-water solution," International Journal of Hydrogen, vol. 37, no. 22, pp. 17002-17008, 2012.

[9] P. Gomathisankar, K. Hachisuka, H. Katsumata, T. Suzuki, K. Funasaka, and S. Kaneco, "Photocatalytic hydrogen production with $\mathrm{CuS} / \mathrm{ZnO}$ from aqueous $\mathrm{Na}_{2} \mathrm{~S}+\mathrm{Na}_{2} \mathrm{SO}_{3}$ solution," International Journal of Hydrogen Energy, vol. 38, no. 21, pp. 8625-8630, 2013.

[10] L. Qi, J. Yu, and M. Jaroniec, "Preparation and enhanced visiblelight photocatalytic $\mathrm{H}_{2}$-production activity of CdS-sensitized $\mathrm{Pt} / \mathrm{TiO}_{2}$ nanosheets with exposed (001) facets," Physical Chemistry Chemical Physics, vol. 13, no. 19, pp. 8915-8923, 2011.

[11] G. Lee and M. Kang, "Physicochemical properties of core/shell structured pyrite $\mathrm{FeS}_{2}$ /anatase $\mathrm{TiO}_{2}$ composites and their photocatalytic hydrogen production performances," Current Applied Physics, vol. 13, no. 7, pp. 1482-1489, 2013.

[12] J. Kim and M. Kang, "High photocatalytic hydrogen production over the band gap-tuned urchin-like $\mathrm{Bi}_{2} \mathrm{~S}_{3}$-loaded $\mathrm{TiO}_{2}$ composites system," International Journal of Hydrogen Energy, vol. 37, no. 10, pp. 8249-8256, 2012.

[13] J. Kim, Y. Sohn, and M. Kang, "New fan blade-like coreshell $\mathrm{Sb}_{2} \mathrm{Ti}_{x} \mathrm{~S}_{y}$ photocatalytic nanorod for hydrogen production from methanol/water photolysis," International Journal of Hydrogen Energy, vol. 38, no. 10, pp. 2136-2143, 2013.

[14] P. Gao, J. Liu, T. Zhang, D. D. Sun, and W. Ng, "Hierarchical $\mathrm{TiO}_{2} / \mathrm{CdS}$ "spindle-like" composite with high photodegradation and antibacterial capability under visible light irradiation," Journal of Hazardous Materials, vol. 229-230, pp. 209-216, 2012.

[15] H. Lee, Y. Park, and M. Kang, "Synthesis of characterization of $\mathrm{Zn}_{x} \mathrm{Ti}_{y} \mathrm{~S}$ and its photocatalytic activity for hydrogen production from methanol/water photo-splitting," Journal of Industrial and Engineering Chemistry, vol. 19, no. 4, pp. 1162-1168, 2013.

[16] C. Xing, Y. Zhang, W. Yan, and L. Guo, "Band structurecontrolled solid solution of $\mathrm{Cd}_{1-x} \mathrm{Zn}_{x}$ S photocatalyst for hydrogen production by water splitting," International Journal of Hydrogen Energy, vol. 31, no. 14, pp. 2018-2024, 2006.

[17] T. T. ThanhThuy, P. Sheng, C. Huang et al., "Synthesis and photocatalytic application of ternary $\mathrm{Cu}-\mathrm{Zn}-\mathrm{S}$ nanoparticlesensitized $\mathrm{TiO}_{2}$ nanotube arrays," Chemical Engineering Journal, vol. 210, pp. 425-431, 2012.

[18] K. W. Cheng and C. J. Liang, "Preparation of Zn-In-S film electrodes using chemical bath deposition for photoelectrochemical applications," Solar Energy Materials and Solar Cells, vol. 94, no. 6, pp. 1137-1145, 2010.

[19] S. Sahai, M. Husain, V. Shanker, N. Singh, and D. Haranath, "Facile synthesis and step by step enhancement of blue photoluminescence from Ag-doped ZnS quantum dots," Journal of Colloid and Interface Science, vol. 357, no. 2, pp. 379-383, 2011.

[20] F. Jia, Z. Yao, and Z. Jiang, "Solvothermal synthesis ZnS- $\operatorname{In}_{2} \mathrm{~S}_{3}$ $\mathrm{Ag}_{2} \mathrm{~S}$ solid solution coupled with $\mathrm{TiO}_{2-x} \mathrm{~S}_{x}$ nanotubes film for photocatalytic hydrogen production," International Journal of Hydrogen Energy, vol. 37, no. 4, pp. 3048-3055, 2012.

[21] J. U. Kim, Y. K. Kim, and H. Yang, "Reverse micelle-derived Cudoped $\mathrm{Zn}_{1-x} \mathrm{Cd}_{x} \mathrm{~S}$ quantum dots and their core/shell structure," Journal of Colloid and Interface Science, vol. 341, no. 1, pp. 59-63, 2010.

[22] K. W. Cheng, C. M. Huang, Y. C. Yu, C. T. Li, C. K. Shu, and W. L. $\mathrm{Liu}$, "Photoelectrochemical performance of $\mathrm{Cu}$-doped $\mathrm{ZnIn}_{2} \mathrm{~S}_{4}$ electrodes created using chemical bath deposition," Solar Energy Materials and Solar Cells, vol. 95, no. 7, pp. 1940-1948, 2011.

[23] J. Sun, G. Chen, G. Xiong, J. Pei, and H. Dong, "Hierarchical microarchitectures of $\mathrm{AgGa}_{1-x} \operatorname{In}_{x} \mathrm{~S}_{2}$ : long chain alcohol assisted synthesis, band gap tailoring and photocatalytic activities of hydrogen generation," International Journal of Hydrogen Energy, vol. 38, no. 25, pp. 10731-10738, 2013.

[24] H. Qi, J. Huang, L. Cao, J. Wu, and J. Li, "Controlled synthesis and optical properties of doughnut-aggregated hollow spherelike CuS," Ceramics International, vol. 38, no. 8, pp. 6659-6664, 2012.

[25] J. Zhang, J. Yu, Y. Zhang, Q. Li, and J. R. Gong, "Visible light photocatalytic $\mathrm{H}_{2}$-production activity of $\mathrm{CuS} / \mathrm{ZnS}$ porous nanosheets based on photoinduced interfacial charge transfer," Nano Letters, vol. 11, no. 11, pp. 4774-4779, 2011.

[26] J. Yu and J. Ran, "Facile preparation and enhanced photocatalytic $\mathrm{H}_{2}$-production activity of $\mathrm{Cu}(\mathrm{OH})_{2}$ cluster modified $\mathrm{TiO}_{2}$ ," Energy and Environmental Science, vol. 4, no. 4, pp. 1364-1371, 2011.

[27] J. Zhang, Z. Liu, B. Han et al., "Preparation of silica and $\mathrm{TiO}_{2}$ $\mathrm{SiO}_{2}$ core-shell nanoparticles in water-in-oil microemulsion using compressed $\mathrm{CO}_{2}$ as reactant and antisolvent," Journal of Supercritical Fluids, vol. 36, no. 3, pp. 194-201, 2006.

[28] J. Du, G. Zhao, H. Pang, Y. Qian, H. Liu, and D. J. Kang, "A template method for synthesis of porous Sn-doped $\mathrm{TiO}_{2}$ monolith and its enhanced photocatalytic activity," Materials Letters, vol. 93, pp. 419-422, 2013.

[29] F. Deng, Y. Li, X. Luo, L. Yang, and X. Tu, "Preparation of conductive polypyrrole/ $\mathrm{TiO}_{2}$ nanocomposite via surface molecular imprinting technique and its photocatalytic activity under simulated solar light irradiation," Colloids and Surfaces A, vol. 395, pp. 183-189, 2012.

[30] F. Li, T. Kong, W. Bi, D. Li, Z. Li, and X. Huang, "Synthesis and optical properties of $\mathrm{CuS}$ nanoplate-based architectures by a solvothermal method," Applied Surface Science, vol. 255, no. 12, pp. 6285-6289, 2009.

[31] G. P. Joshi, N. S. Saxena, R. Mangal, A. Mishra, and T. P. Sharma, "Band gap determination of Ni-Zn ferrites," Bulletin of Materials Science, vol. 26, no. 4, pp. 387-389, 2003.

[32] Y. Kim, J. H. Jeong, and M. Kang, "Rapid synthesis of bis (2,2/-bipyridine) nitratocopper(II) nitrate using a hydrothermal method and its application to dye-sensitized solar cells," Inorganica Chimica Acta, vol. 365, no. 1, pp. 400-407, 2011.

[33] S. Giraud, G. Loupias, H. Maskrot et al., "Dip-coating on $\mathrm{TiO}_{2}$ foams using a suspension of $\mathrm{Pt}-\mathrm{TiO}_{2}$ nanopowder synthesized by laser pyrolysis-preliminary evaluation of the catalytic performances of the resulting composites in deVOC reactions," Journal of the European Ceramic Society, vol. 27, no. 2-3, pp. 931936, 2007.

[34] J. Zhang, J. Yu, M. Jaroniec, and J. R. Gong, "Noble metalfree reduced graphene oxide- $\mathrm{ZnxCd}_{1-x} \mathrm{~S}$ nanocomposite with enhanced solar photocatalytic $\mathrm{H}_{2}$ production performance," Nano Letters, vol. 12, pp. 4584-4589, 2012. 

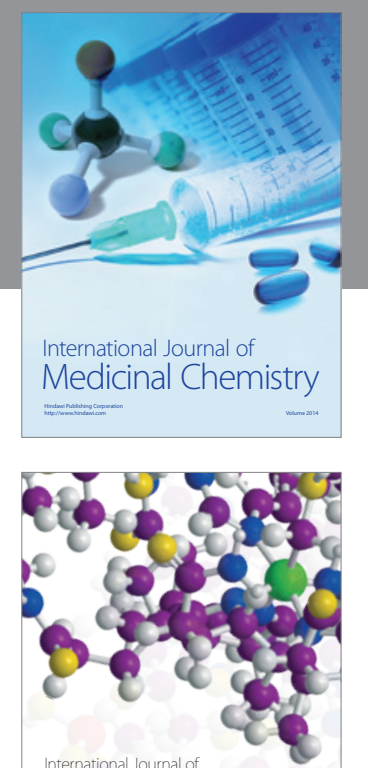

\section{Carbohydrate} Chemistry

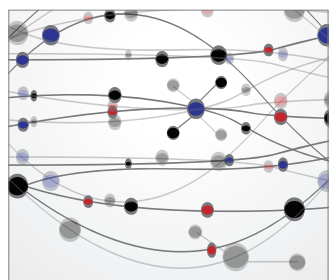

The Scientific World Journal
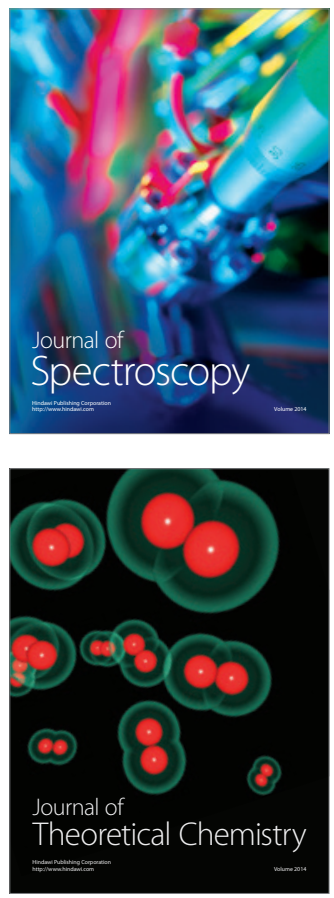
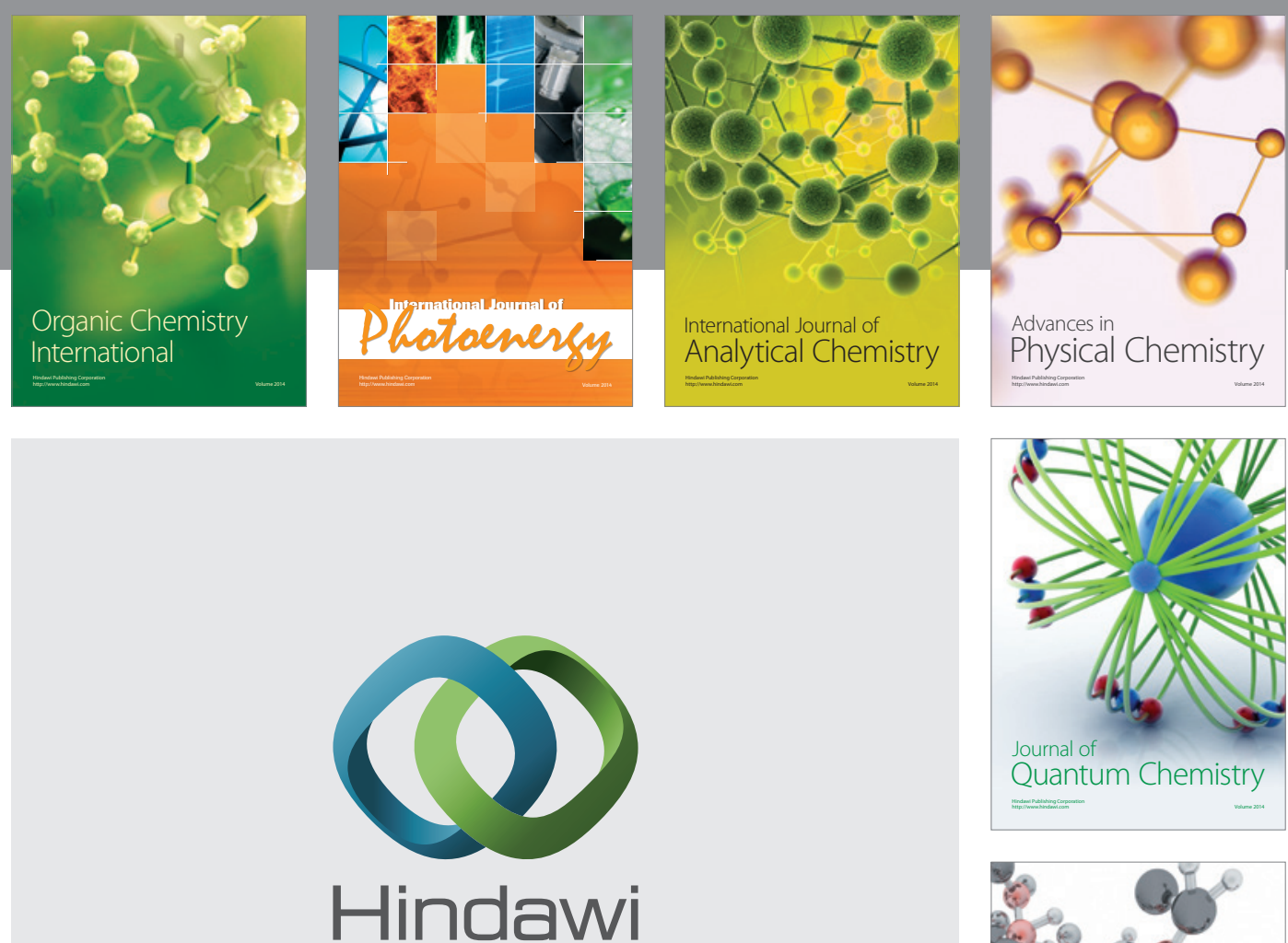

Submit your manuscripts at

http://www.hindawi.com

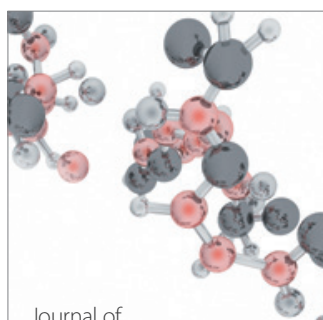

Analytical Methods

in Chemistry

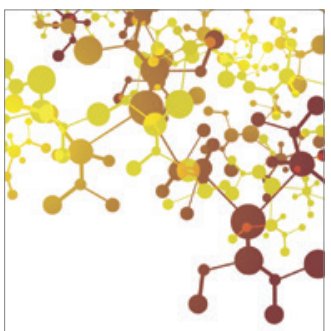

Journal of

Applied Chemistry

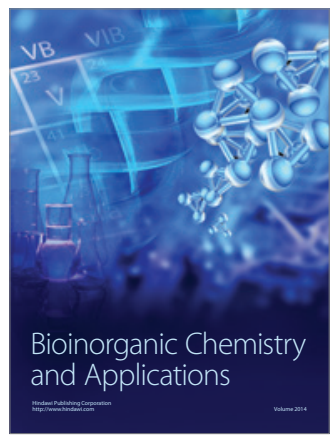

Inorganic Chemistry
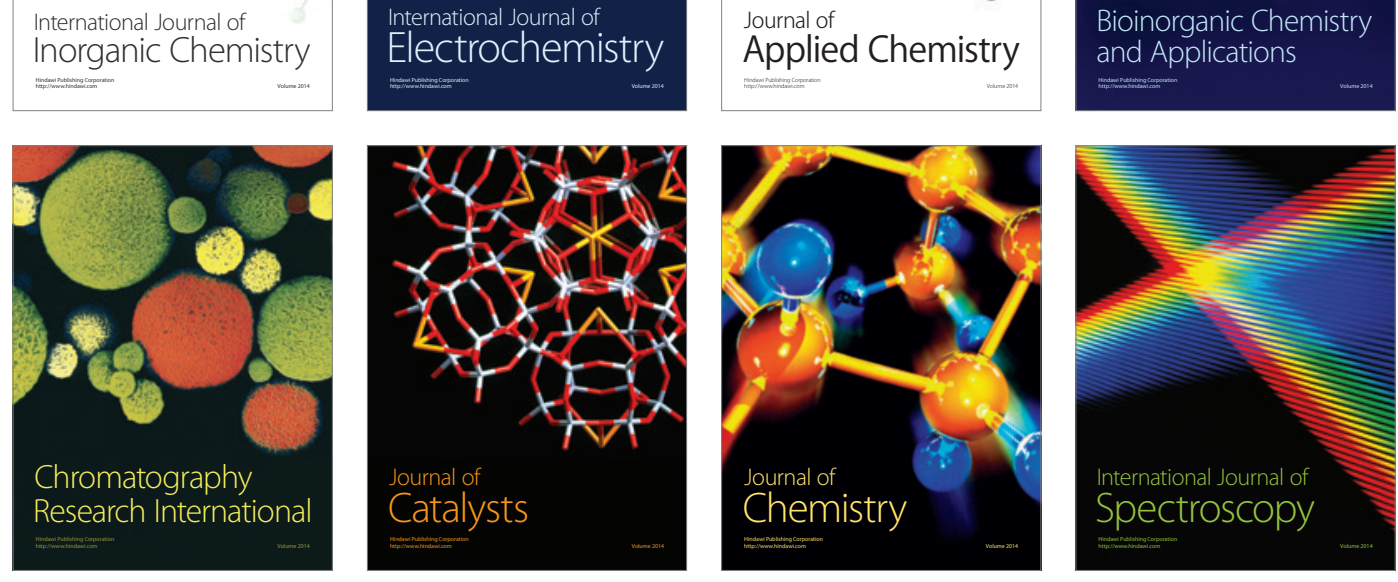